\title{
Establishment and preliminary evaluation of a teaching hospital- based dementia consultation service for rurally-based regional district general hospitals
}

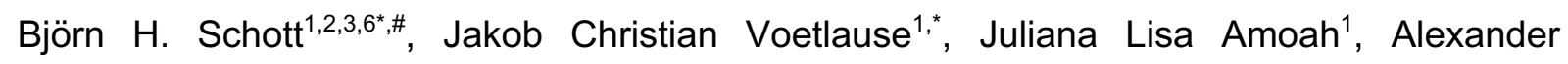
Kratzenberg $^{1}$, Michael Belz ${ }^{1}$, Tobias Knipper ${ }^{1}$, Charles Timäus ${ }^{1}$, Carmen Beskow ${ }^{1}$, Catherine M. Sweeney-Reed ${ }^{5,6}$, Jens Wiltfang ${ }^{1,2,4}$, and Katrin Radenbach ${ }^{1, \#}$

${ }^{1}$ Department of Psychiatry and Psychotherapy, University Medical Center Göttingen, Göttingen, Germany

${ }^{2}$ German Center for Neurodegenerative Diseases, Göttingen, Germany

${ }^{3}$ Leibniz Institute for Neurobiology, Magdeburg, Germany

${ }^{4}$ Neurosciences and Signaling Group, Institute of Biomedicine (iBiMED), Department of Medical Sciences, University of Aveiro, Aveiro, Portugal

${ }^{5}$ Neurocybernetics and Rehabilitation, Dept. of Neurology, Otto von Guericke University Magdeburg, Magdeburg, Germany

${ }^{6}$ Center for Behavioral Brain Sciences, Otto von Guericke University Magdeburg, Magdeburg, Germany

*These authors contributed equally to this work

${ }^{\#}$ Corresponding authors:

Dr. Katrin Radenbach \& Dr. Björn Schott

Department of Psychiatry and Psychotherapy

University Medical Center Göttingen

Von Siebold-Str. 5

37075 Göttingen, Germany

katrin.radenbach@med.uni-goettingen.de

bjoernhendrik.schott@med.uni-goettingen.de 
medRxiv preprint doi: https://doi.org/10.1101/2021.10.14.21264940; this version posted October 18, 2021. The copyright holder for this preprint (which was not certified by peer review) is the author/funder, who has granted medRxiv a license to display the preprint in It is made available under a CC-BY-NC-ND 4.0 International license.

\section{Abstract}

The treatment of patients with dementia poses a considerable challenge to regional district general hospitals, particularly in rural areas. Here we report the establishment and initial evaluation of a dementia-specific consultation service provided by a teaching hospital-based Psychiatry Department to regional district general hospitals in smaller surrounding towns. The service was provided to patients both with pre-existing and newly diagnosed or suspected dementia, who were in acute hospital care for concurrent conditions. An initial evaluation of 61 consultations - 49 on-site and 12 via telemedicine - was performed to assess the needs of the participating hospitals and the specific nature of the referrals to the consultation service. Suspected dementia or cognitive dysfunction was the primary reason for consultation requests ( $>50 \%$ of cases). Other common requests concerned suspected delirium, behavioral disturbances, and therapeutic recommendations. During the consultations, a diagnosis of dementia was reached in $52.5 \%$ of cases, with other common diagnoses including delirium and depression. Recommendations related to pharmacotherapy were given in $54.1 \%$ of consultations. Other recommendations included referral for outpatient neurological or psychiatric follow-up, further diagnostic assessment, or assessment in a memory clinic. Geriatric psychiatric inpatient treatment was recommended in only seven cases (11.5\%). Our initial evaluation demonstrates the feasibility of providing a dementia-specific consultation service in a rural area. The service has the potential to reduce acute transfers to inpatient geriatric psychiatry and enables older patients with dementia or delirium to be treated locally by helping and empowering rurally-based regional hospitals to manage these problems and associated complications. 
medRxiv preprint doi: https://doi.org/10.1101/2021.10.14.21264940; this version posted October 18, 2021. The copyright holder for this preprint (which was not certified by peer review) is the author/funder, who has granted medRxiv a license to display the preprint in It is made available under a CC-BY-NC-ND 4.0 International license .

\section{Introduction}

Patients with dementia admitted to hospital for acute treatment of concurrent conditions are at increased risk of complications and adverse events such as falls, delirium, or severe behavioral disturbances, culminating in overall higher mortality ${ }^{1-3}$. Advanced age is the primary risk factor for developing dementia, and the proportion of individuals affected by dementia is therefore increasing steeply in aging populations, such as in most European countries ${ }^{4}$.

The situation of people with dementia in hospital is frequently complicated by other related conditions, which may present similarly, yet necessitate a different or more comprehensive treatment approach. A cardinal example is delirium, which is common following surgery ${ }^{5}$, and can be aggravated by inadequate medication ${ }^{1}$. Delirium typically results in prolonged length of inpatient stay and a short-term 20 -fold increase in mortality. A quarter of older patients with delirium die within three to four months, and $41 \%$ of previously self-caring individuals require discharge to a nursing facility. Symptoms are fully reversible in approximately $50 \%$ of cases ${ }^{6}$, but recovery may depend on timely recognition and initiation of appropriate treatment. Another challenge in the care of the elderly, and especially patients with dementia, is the frequent polypharmacy, which refers to the use of four to five or even more medications at the same time. Even in the absence of obvious side-effects, polypharmacy must be regarded as a risk factor for the occurrence of complications like delirium or behavioral disorders. Such complications can arise because numerous pharmaceuticals, for example loop diuretics ${ }^{7}$ or digitalis glycosides ${ }^{8}$, are generally capable of triggering delirium in predisposed patients. Furthermore, psychotropic medications frequently used for behavioral disorders may themselves induce considerable somatic and psychiatric side-effects ${ }^{6}$.

Several approaches have been proposed to improve the care for patients with dementia and to prevent delirium in acute care hospitals. Interventions to improve care in general include patient-centered care provided by hospital staff ${ }^{9}$ or the training of volunteers ${ }^{3}$. To specifically reduce the incidence of delirium, both non-pharmacological ${ }^{10}$ and pharmacological ${ }^{11}$ interventions show moderate effectiveness, but there is considerable variability concerning the benefit for the individual patient.

While these approaches are promising and are currently being further developed, their applicability may be particularly challenging in smaller, rural hospitals: In addition to the increasing average age of the population, younger individuals frequently concentrate in larger cities, leaving small towns and rural areas predominantly affected by the consequences of having an aging population ${ }^{12}$. This trend leads to a disproportionately increasing number of patients with dementia in rural hospitals, and at the same time, contributes to the lack of qualified staff to support specialized units for dementia treatment and care, such as neurology or (geriatric) psychiatry departments ${ }^{13,14}$. Here we propose and evaluate the feasibility of an 
medRxiv preprint doi: https://doi.org/10.1101/2021.10.14.21264940; this version posted October 18, 2021. The copyright holder for this preprint (which was not certified by peer review) is the author/funder, who has granted medRxiv a license to display the preprint in It is made available under a CC-BY-NC-ND 4.0 International license

out-reach consultation service provided by a specialized institution within rural surroundings to alleviate this problem.

We report the establishment of a dementia-specific consultation service to improve the care for patients with dementia treated in rurally-based regional hospitals. The service as described here was provided by the Department of Psychiatry and Psychotherapy of the University Medical Center Göttingen, Germany, and was available for patients treated in local regional hospitals upon request by their treating clinicians. An initial evaluation was performed to assess the needs and questions commonly raised by the treating hospitals as well as recommendations commonly made by the providers of the service. 
medRxiv preprint doi: https://doi.org/10.1101/2021.10.14.21264940; this version posted October 18, 2021. The copyright holder for this preprint (which was not certified by peer review) is the author/funder, who has granted medRxiv a license to display the preprint in It is made available under a CC-BY-NC-ND 4.0 International license .

\section{Methods}

\subsection{Establishment of a dementia consultation service}

\subsubsection{Preparatory work}

The proposal for establishing a dementia-specific consultation service for rurally-based regional hospitals was initially developed as part of an initiative funded by the Department of Social Affairs, Health and Equality of the State of Lower Saxony ${ }^{15}$. The study was approved by the Ethics Committee of the University Medical Center Göttingen (approval number 13/12/19) and was registered with the German Clinical Trials Register (registration number DRKS00022366).

\subsubsection{Setting and participating hospitals}

The consultation service was provided by the Department of Psychiatry and Psychotherapy of the University Medical Center Göttingen (UMG). The university city of Göttingen, with a population of 118,911 (December 2019, https://www.statistik.niedersachsen.de), is surrounded by the rural counties of Göttingen (county), Goslar, and Northeim. We identified nine hospitals without in-house Psychiatry and/or Neurology Departments in the assigned service area of the Department of Psychiatry and Psychotherapy of the UMG.

\subsubsection{Team}

The team consisted of two senior residents in psychiatry (T.K. and C.-A.T.), a nurse with long-standing experience in geriatric psychiatry and dementia care (C.B.), as well as a project coordinator (A.K.) and two research students (J.C.V. and J.L.A.). Organizational and clinical supervision was carried out by two senior psychiatrists specialized in geriatric psychiatry and/or consultant liaison psychiatry (K.R. and B.H.S.).

\subsubsection{Legal issues and service agreements}

The service agreement was drawn up in collaboration with the UMG's legal department. After a formal presentation of the project was held in a partner hospital expressing interest, the written service agreements were sent to the respective hospital for review if further interest was expressed. Upon mutual agreement, the service agreements were signed by the Medical Director of the Department of Psychiatry and Psychotherapy of the UMG and the board members (UMG and partner hospital). Service agreements were established with five partner hospitals, including four general care hospitals and one hospital specialized in interdisciplinary diabetes care. Agreements were signed between 18.05.2020 and 21.07.2020.

\subsection{Implementation of the consultation service}

\subsubsection{Request and performance of consultations}

Information regarding the process of requesting consultations, including contact options, was provided to the hospitals as a flowchart during the initial project visit. Consultations could 
medRxiv preprint doi: https://doi.org/10.1101/2021.10.14.21264940; this version posted October 18, 2021. The copyright holder for this preprint (which was not certified by peer review) is the author/funder, who has granted medRxiv a license to display the preprint in It is made available under a CC-BY-NC-ND 4.0 International license .

be requested by phone, e-mail, or fax. They included history and neuropsychiatric examination and were performed either on-site or via telemedical service, and were followed by recommendations regarding diagnostic and therapeutic measures. Further diagnostic assessment for the differential diagnosis of a dementia syndrome or its complications was recommended where applicable, as well as specific therapies and support from Social Services. Specific attention was paid to complex polypharmacy, and advice was given by physicians on how to avoid possible pharmacological risk factors for deterioration of the patient's condition (e.g., by avoiding potentially delirium-inducing substances).

An educational program complemented the consultation service. The program included both scheduled talks on selected topics concerning dementia treatment and care as well as hands-on teaching. A nurse with long-standing experience in geriatric psychiatry and dementia care supported the nursing staff on-site by providing advice on the nursing management of patients with dementia, including means of communication and improving the hospital environment to meet the special needs of these patients. Advice was provided both in general and on a case-by-case basis. A detailed evaluation of the educational program and the local expertise form part of a separate, ongoing, study.

\subsubsection{Standardized documentation of consultations}

A standardized form was used for systematic clinical documentation of the consultations, including the questions leading to consultation, a detailed medical and psychiatric history, and the recommendations made by the providing physician. The questionnaire was available in both digital and paper form (see Appendix). The Mini-Mental State Examination (MMSE) was additionally administered to a total of 40 patients. While primarily designed to meet the clinical needs of the requesting institutions, these standardized forms also provided the basis for the statistical evaluation of the consultations reported here.

\subsection{Preliminary evaluation}

\subsubsection{Data extraction and statistical analysis}

A central aspect of the current study was the evaluation of the questions raised by the partner institutions when requesting our consultation service for an individual patient. The circumstances leading to initiation of the consultations were also considered. Since the wording of questions arising under comparable circumstances varied, we performed a content analysis using inductive categorization to enable quantitative analyses ${ }^{16}$. As consultation forms were primarily completed to meet the needs of the referring clinicians, the categories were defined according to the existing content. For example, the category Suspected Dementia included questions regarding dementia, memory impairment, and cognitive decline, whereas questions concerning confusion and disorientation were also assigned to the category 
medRxiv preprint doi: https://doi.org/10.1101/2021.10.14.21264940; this version posted October 18, 2021. The copyright holder for this preprint (which was not certified by peer review) is the author/funder, who has granted medRxiv a license to display the preprint in It is made available under a CC-BY-NC-ND 4.0 International license

Suspected Delirium. Furthermore, questions relating to drug intolerance and to recommendations on pharmacotherapy were included in a single category (Pharmacological Issues): referring clinicians typically requested advice regarding a potential change or discontinuation of medication in both areas.

Given the preliminary nature of the current evaluation, we report our findings primarily as frequency data. Where inference statistics were applicable, $\chi^{2}$ tests were used to evaluate frequency deviations, and t-tests were applied to continuous data. Owing to the relatively small sample sizes, unequal variances were assumed in independent-sample t-tests (i.e., Welch's ttests were used). 
medRxiv preprint doi: https://doi.org/10.1101/2021.10.14.21264940; this version posted October 18, 2021. The copyright holder for this preprint (which was not certified by peer review) is the author/funder, who has granted medRxiv a license to display the preprint in It is made available under a CC-BY-NC-ND 4.0 International license .

\section{Results}

\subsection{Consultations performed across participating institutions}

The consultations analyzed took place from 10.07 .2020 to 14.03 .2021 . Within the study period, 65 consultations were performed, four of which were follow-up consultations provided for patients who had already been examined previously, in order to follow the subsequent course of their condition and to potentially adapt diagnostics and therapy accordingly. The sample thus consists of 65 consultations for 61 patients. The following general evaluation of the data is based on the number of patients $(\mathrm{N}=61)$.

Despite limitations imposed by the ongoing COVID-19 pandemic during the study period, the majority of consultations ( $N=49,80.3 \%$ ) were performed on-site (Figure $1 \mathrm{~A}$ ). The number of requests varied considerably between the participating hospitals ( $N=5$; Figure $1 B$ ), significantly deviating from an equal distribution $\left(\chi^{2}(4)=77.93, p<.001\right)$, with more than half of the consultations requested by one hospital (Figure 1B).

\subsection{Demographic and clinical characteristics of the patients}

\subsubsection{Demographics of the patients}

Among the patients in our sample, more than half were 80 years or older (Figure 1C), and the number of women in the age groups of 80 years and above was higher compared to men (Figure 1D). The average age of women among the patients was 82.5 years (men: 73.1 years, $t(27.7)=2.94, p=.007)$. While this asymmetry was generally in line with the higher life expectancy among women, it should be noted that the proportion of men $(n=19)$ was still lower than would be expected based on the general population ${ }^{17}$.

\subsubsection{Conditions leading to hospital admission and indications for consultation requests}

The conditions leading to acute admission to the partner hospitals were categorized according to the relevant medical specialty or the specific reason for admission. In absolute numbers, the most common reasons for patients' admission to the partner hospitals were problems classified under Surgery (Figure 2A), with falls being the most frequently reported event leading to admission ( $\mathrm{N}=15,24.6 \%$ ). Other common reasons were categorized under Internal Medicine, Neurology or Psychiatry, and planned adaptation or modification of pharmacotherapy. The latter arose particularly at the partner hospital specializing in the treatment of diabetes. Notably, in 17 cases (27.9\%), the primary reasons for admission to the partner hospitals were neuropsychiatric problems, although the partner hospitals had neither neurology nor psychiatry departments.

The most common symptoms reported to the service by the partner institutions when requesting a consultation could be classified as being related to Behavioral Disturbances, Risk of Falls, Cognitive Impairment, and Sleep Disorders (Figure 2B). Following data extraction, the 
medRxiv preprint doi: https://doi.org/10.1101/2021.10.14.21264940; this version posted October 18, 2021. The copyright holder for this preprint (which was not certified by peer review) is the author/funder, who has granted medRxiv a license to display the preprint in It is made available under a CC-BY-NC-ND 4.0 International license .

questions were classified as indications for consultation and assigned to the following categories: Suspected Dementia, Suspected Delirium, Behavioral Symptoms in Dementia, Pharmacological Issues and Suspected Depression (Figure 2B).

In line with the focus of our consultation service on dementia, over half of consultation requests (50.8\%, Figure $2 \mathrm{C}$ ) were related to suspected dementia and/or cognitive impairment, and over a fifth (23.0\%) specifically concerned behavioral symptoms in dementia. Questions relating to pharmacotherapy comprised both suspected adverse effects and requests for recommendations regarding pharmacological treatment.

\subsubsection{Pre-existing conditions and risk factors}

A pre-existing confirmed diagnosis of dementia was reported in only nine consultation requests (14.8\%) (Figure 3A). More broadly, a previous history of cognitive deficits was reported in 22 patients (36.1\%), suggesting that dementia or cognitive impairment in older adults may be underdiagnosed among patients in rural primary care hospitals.

Beyond dementia and cognitive dysfunction, 38 patients $(64.4 \%)$ had a history of at least three chronic medical conditions, and $23(39.0 \%)$ had six or more diagnoses of a chronic disease. Considering the importance of delirium in the differential diagnosis for dementia and as a risk factor for morbidity and mortality in older adults ${ }^{6}$, risk factors for developing delirium were specifically explored. Acute or chronic pain, hearing or visual impairment, recent surgical procedures, and infections were noted most frequently (Figure 3B).

\subsection{Consultations}

\subsubsection{Diagnostic assessment}

Mirroring the focus of the consultation requests on suspected dementia, the group of dementias (ICD-10: F00 - F03) constituted the diagnoses made most frequently by the physicians performing the consultations (Figure 4A). Further diagnoses typically associated with cognitive disturbance included delirium (ICD-10: F05.x, F1x.4) and mild cognitive impairment (MCl; ICD-10: F06.7), a risk state for dementia ${ }^{18}$. Notably, among the dementia subtypes, vascular dementias were most frequently recorded as diagnoses (Figure 4B), despite dementia in Alzheimer's disease being the most common form of dementia in the population ${ }^{19}$. The $\mathrm{MMSE}^{20}$ was performed in 40 patients (Figure $4 \mathrm{C}$ ), and the average MMSE score was lower in patients with a diagnosis of dementia $(18.86 \pm 5.16)$ than in those with other diagnoses $(22.75 \pm 5.01 ; \mathrm{t}(21.7)=22.23, \mathrm{p}=0.016)$. As expected, polypharmacy was highly prevalent among the patients referred for consultation, with a median number of 10 different medications (range: $2-23$; mean $=10.31 \pm 5.01$; Figure 4D). There was, however, no difference in the number of medications as a function of dementia diagnosis or delirium (all $p$ $>0.468)$. 
medRxiv preprint doi: https://doi.org/10.1101/2021.10.14.21264940; this version posted October 18, 2021. The copyright holder for this preprint (which was not certified by peer review) is the author/funder, who has granted medRxiv a license to display the preprint in It is made available under a CC-BY-NC-ND 4.0 International license

\subsubsection{Recommendations}

The physicians performing the consultations made a wide range of recommendations (Figure 5A). Recommendations regarding pharmacotherapy given most frequently $(54.1 \%$ of patients). Among these, initiation of novel pharmacological treatment, including medication to be administered as required (pro re nata, PRN), was most commonly recommended, followed by discontinuation or reduction, and change of medication, which were recommended with equal frequency (Figure 5B). Non-pharmacological measures to treat behavioral disturbances were recommended for six patients $(9.8 \%)$, but it should be noted that assistance with nonpharmacological interventions was primarily provided by the geriatric nurse (C.B.), who interacted with the nursing staff of the participating hospitals largely independently and provided advanced training in non-pharmacological treatment of dementia patients.

Further diagnostic assessment, referral for outpatient neuropsychiatric treatment, or consultation at a memory clinic were also frequently recommended. For seven patients (11.5\%), transfer to a geriatric psychiatric inpatient ward was recommended. Follow-up consultations were recommended for seven patients but were subsequently requested and performed for four patients only. 
medRxiv preprint doi: https://doi.org/10.1101/2021.10.14.21264940; this version posted October 18, 2021. The copyright holder for this preprint (which was not certified by peer review) is the author/funder, who has granted medRxiv a license to display the preprint in It is made available under a CC-BY-NC-ND 4.0 International license .

\section{Discussion}

The main goal of the study, the establishment of a combined outreach and telemedical dementia consultation service for rurally-based regional district general hospitals, was successfully achieved despite the obstacles posed by the ongoing COVID-19 pandemic. The requests received from the participating hospitals emphasize the need for the dissemination of expertise in dementia treatment and care among smaller hospitals in rural areas.

\subsection{Implementation and evaluation of the consultations}

The basic goal of the project, to improve the general care of people with dementia in rurallybased regional hospitals, was achieved: Agreements were signed with five partner hospitals, and consultations were performed for all five institutions, albeit with considerably varying frequency. Notably, over half of the consultations were requested by one of the participating hospitals. This tendency is probably best explained by the fact that this hospital has a geriatric department, which treats a large number of people with dementia, and the staff in this department may be more sensitive to the presence of cognitive or behavioral disturbances.

Across all participating hospitals, consultations were predominantly requested in relation to previously diagnosed or suspected dementia or associated behavioral problems (Figure 2C), confirming the need for a dementia-specific consultation service. Other frequent diagnoses included delirium, which is often difficult to distinguish cross-sectionally from dementia $^{1}$, and depressive syndromes, which are an important part of the differential diagnosis, especially in individuals with subjectively reported cognitive disturbance ${ }^{21}$.

Somewhat unexpectedly, the diagnosis of vascular dementia was the most frequently diagnosed form of dementia during the consultations. Given that dementia due to Alzheimer's disease is the most common form in older adults ${ }^{19}$, we cannot exclude the possibility that some patients diagnosed with vascular dementia may nevertheless have had amyloid pathology and would thus have to be correctly classified as having mixed dementia. This differential diagnosis was, however, difficult to make as part of the consultation and should be performed, for example, in a memory clinic ${ }^{22}$.

More than $70 \%$ of the patients treated were receiving eight or more medications (Figure 4D), emphasizing the importance of considering the risks associated with polypharmacy in older patients, and particularly those with dementia, or more generally, cognitive impairment ${ }^{3,6}$. Accordingly, in more than $50 \%$ of the consultations, an adjustment of pharmacotherapy was recommended, which commonly involved dose reduction or discontinuation, as well as replacement with medication with a more favorable side-effect profile (Figure 5). We note that the number of medications taken by a given patient was independent of patient age, degree of cognitive impairment, and diagnosis reached. Although such dependencies may become 
medRxiv preprint doi: https://doi.org/10.1101/2021.10.14.21264940; this version posted October 18, 2021. The copyright holder for this preprint (which was not certified by peer review) is the author/funder, who has granted medRxiv a license to display the preprint in It is made available under a CC-BY-NC-ND 4.0 International license .

apparent in a larger study population, the finding underlines the importance of service provision for this patient group that is not limited to tight criteria but rather is based on communication with colleagues at the partner hospitals.

A direct transfer to a (geriatric) psychiatric inpatient unit was recommended in only $11.5 \%$ of cases. This low referral rate indicates that acute transfers of people with dementia to psychiatric departments - often associated with great distress for those affected - can possibly be at least partially avoided by providing adequate outreach consultation services. While further neurological or psychiatric assessment was indeed frequently recommended, it can often take place in an outpatient setting. The frequent recommendation of further diagnostic assessment, referral for outpatient neuropsychiatric treatment, or consultation at a memory clinic reflect the fact that dementia and cognitive impairment are chronic conditions that cannot be adequately treated in a single hospital stay. Access to the proposed consultation service meant that these unmet needs could be identified and seamlessly addressed by appropriate specialist facilities following the acute hospital stay, as opposed to requiring a subsequent separate assessment in the community before the necessary referral could be made.

\subsection{Partnership with participating hospitals}

Implementing a partnership with external hospitals (partly under private ownership) requires establishment of continuous communication. Individual approaches and intense exchange were essential in building a system of shared patient care. Gaining the interest of potential partners in the project was best achieved through personal contact, preferably onsite. Establishing contact via letter or e-mail remained more challenging, presumably due to the limited time capacities of the respective chief and senior physicians. Once the partnership had been established, it was essential to have fixed contact persons at the respective partner hospitals, who were aware of the possibility of dementia-specific consultations and could both request consultations and distribute information regarding our service. The establishment of a routine with fixed appointments and contact persons proved helpful for regular consultation requests. Telemedical consultations were not possible at all sites due to limited Wi-Fi and other technical factors. The successful implementation of this service in 12 cases, however, provides support for the feasibility of such an approach, which may grow in relevance during the current COVID-19 pandemic as well as future potential pandemics, in which this patient group is at high risk of serious consequences of infection, due to both advanced age and comorbidity. A specialist consultation service can provide diagnostic assessment and treatment plans without increasing social contact and infection risk.

The role of the nurse in providing non-pharmacological interventions underlines the requirement for a multidisciplinary service to address the clinical needs of this patient group. 
medRxiv preprint doi: https://doi.org/10.1101/2021.10.14.21264940; this version posted October 18, 2021. The copyright holder for this preprint (which was not certified by peer review) is the author/funder, who has granted medRxiv a license to display the preprint in It is made available under a CC-BY-NC-ND 4.0 International license.

\subsection{Conclusion and perspectives}

Our findings indicate that provision of a dementia-specific consultation service for rurallybased, regional district general hospitals is feasible for university-based geriatric psychiatric units. We suggest that the concept of the dementia consultation service provided by a tertiary referral center (e.g., university hospital) to surrounding regional hospitals may provide a helpful addition to improve care for patients with dementia in rural areas. The service has the potential to reduce acute transfers to in-patient geriatric psychiatry. It enables older patients with dementia or delirium to be treated locally by assisting and empowering rurally-based regional hospitals to manage these problems and associated complications. Future studies are required to provide a more extensive evaluation of these effects. As our project was tailored to meet the capacities and needs of the German healthcare system, future research should also investigate to what extent the concept is transferrable to other geographic regions with comparable organization of hospital care.

\section{Notes}

\subsection{Author contributions}

B.H.S., J.W., and K.R. conceived and designed the study and acquired funding; A.K. coordinated the consultation service; T.K. and C.A.T. performed the medical consultations; C.B. performed the nursing consultations; B.H.S. and K.R. supervised consultations; J.C.V., J.L.A., and A.K. performed data curation; B.H.S., J.C.V., and M.B. analyzed the data; B.H.S. and J.C.V. wrote the first draft of the manuscript; C.M.S.R., B.H.S., M.B. and K.R. interpreted the analyses and edited the manuscript; all authors contributed to editing and critically revising the manuscript.

\subsection{Acknowledgments}

The authors would like to thank the staff of all participating hospitals. We thank Thomas Voigt and Matthias Siegert from the legal department of the UMG for support drafting the agreements and Petra Arndt, Hermann Esselmann, Ute Gotthardt, Cornelia Hönicke, Tobias Urbanczyk, and David Zilles for help with project administration. We further thank Hermann Esselmann for helpful comments on this manuscript.

\subsection{Funding}

This work was supported by the State of Lower Saxony, Department of Social Affairs, Health and Equal Opportunities (funding reference: 3SL_G.Demenz-04-2019). 
medRxiv preprint doi: https://doi.org/10.1101/2021.10.14.21264940; this version posted October 18, 2021. The copyright holder for this preprint (which was not certified by peer review) is the author/funder, who has granted medRxiv a license to display the preprint in

It is made available under a CC-BY-NC-ND 4.0 International license .

\section{References}

1. Inouye SK, Westendorp RG, Saczynski JS. Delirium in elderly people. Lancet. 2014;383(9920):911-922.

2. Dewing J, Dijk S. What is the current state of care for older people with dementia in general hospitals? A literature review. Dementia (London). 2016;15(1):106-124.

3. Blair A, Anderson K, Bateman C. The "Golden Angels": effects of trained volunteers on specialling and readmission rates for people with dementia and delirium in rural hospitals. Int Psychogeriatr. 2018;30(11):1707-1716.

4. Cao Q, Tan CC, Xu W, et al. The Prevalence of Dementia: A Systematic Review and MetaAnalysis. J Alzheimers Dis. 2020;73(3):1157-1166.

5. Ní Chróinín D, Francis N, Wong P, Kim YD, Nham S, D'Amours S. Older trauma patients are at high risk of delirium, especially those with underlying dementia or baseline frailty. Trauma Surg Acute Care Open. 2021;6(1):e000639.

6. Inouye SK, Marcantonio ER, Metzger ED. Doing Damage in Delirium: The Hazards of Antipsychotic Treatment in Elderly Persons. Lancet Psychiatry. 2014;1(4):312-315.

7. Sica DA. Diuretic-related side effects: development and treatment. J Clin Hypertens (Greenwich). 2004;6(9):532-540.

8. Marvanova M. Drug-induced cognitive impairment: Effect of cardiovascular agents. Ment Health Clin. 2016;6(4):201-206.

9. Chenoweth L, Williams A, Fry M, Endean E, Liu Z. Outcomes of Person-centered Care for Persons with Dementia in the Acute Care Setting: A Pilot Study. Clin Gerontol. 2021:1-15.

10. Burton JK, Craig LE, Yong SQ, et al. Non-pharmacological interventions for preventing delirium in hospitalised non-ICU patients. Cochrane Database Syst Rev. 2021;7:Cd013307.

11. Park SK, Lim T, Cho H, et al. Comparative effectiveness of pharmacological interventions to prevent postoperative delirium: a network meta-analysis. Sci Rep. 2021;11(1):11922.

12. Milbert A, Sturm G. Binnenwanderungen in Deutschland zwischen 1975 und 2013. Informationen zur Raumentwicklung. 2016;2:121-144.

13. van den Berg N, Grabe HJ, Freyberger HJ, Hoffmann W. A telephone- and text-message based telemedical care concept for patients with mental health disorders--study protocol for a randomized, controlled study design. BMC Psychiatry. 2011;11:30.

14. Mathur S, Walter S, Grunwald IQ, Helwig SA, Lesmeister M, Fassbender K. Improving Prehospital Stroke Services in Rural and Underserved Settings With Mobile Stroke Units. Front Neurol. 2019;10:159.

15. Niedersächsisches Ministerium für Soziales Gesundheit und Gleichstellung. https://www.ms.niedersachsen.de/startseite/service kontakt/presseinformationen/demenzkran ke-im-krankenhaus-besser-versorgen-land-foerdert-modellprojekte-mit-15-millionen-euro175936.html. Published 2019. Accessed.

16. Mayring P, Fenzl T. Qualitative Inhaltsanalyse. In: Baur N, Blasius J, eds. Handbuch Methoden der empirischen Sozialforschung. Wiesbaden: Wiesbaden; 2014:543-556.

17. Statistisches Bundesamt. https://www.destatis.de/DE/Themen/Querschnitt/DemografischerWandel/ inhalt.html. Published 2021. Accessed.

18. Schmidtke K, Hermeneit S. High rate of conversion to Alzheimer's disease in a cohort of amnestic MCl patients. Int Psychogeriatr. 2008;20(1):96-108.

19. Association As. 2016 Alzheimer's disease facts and figures. Alzheimers Dement. 2016;12(4):459-509.

20. Folstein MF, Folstein SE, McHugh PR. "Mini-mental state". A practical method for grading the cognitive state of patients for the clinician. J Psychiatr Res. 1975;12(3):189-198.

21. Arie T. Pseudodementia. Br Med J (Clin Res Ed). 1983;286(6374):1301-1302.

22. Wallin $\mathrm{A}$, Nordlund $\mathrm{A}$, Jonsson $\mathrm{M}$, et al. The Gothenburg $\mathrm{MCl}$ study: Design and distribution of Alzheimer's disease and subcortical vascular disease diagnoses from baseline to 6-year followup. J Cereb Blood Flow Metab. 2016;36(1):114-131. 
medRxiv preprint doi: https://doi.org/10.1101/2021.10.14.21264940; this version posted October 18, 2021. The copyright holder for this preprint (which was not certified by peer review) is the author/funder, who has granted medRxiv a license to display the preprint in It is made available under a CC-BY-NC-ND 4.0 International license.

\section{Figures}

Figure 1: Basic conditions of the consultation service. A: Proportions of consultations performed on-site or via telemedicine. B: Distribution of the consultation requests among the participating hospitals. C: Age distribution among the patients for whom consultations were requested. D: Age distribution, separated by gender.

A

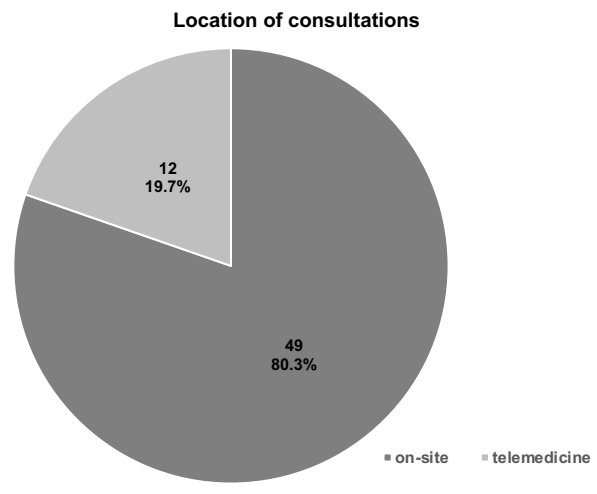

C

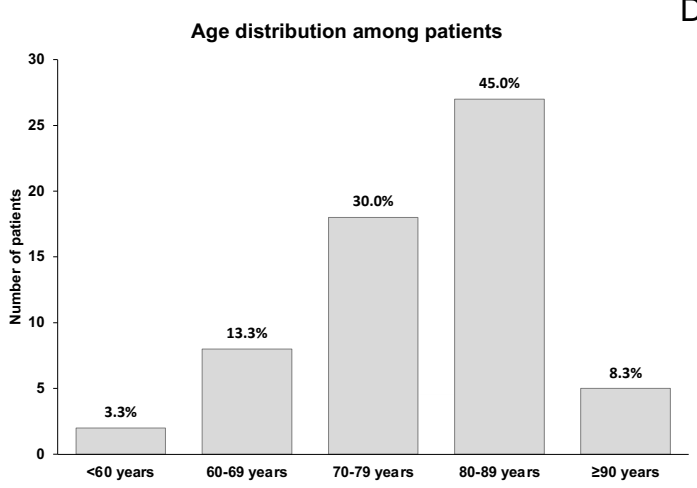

B

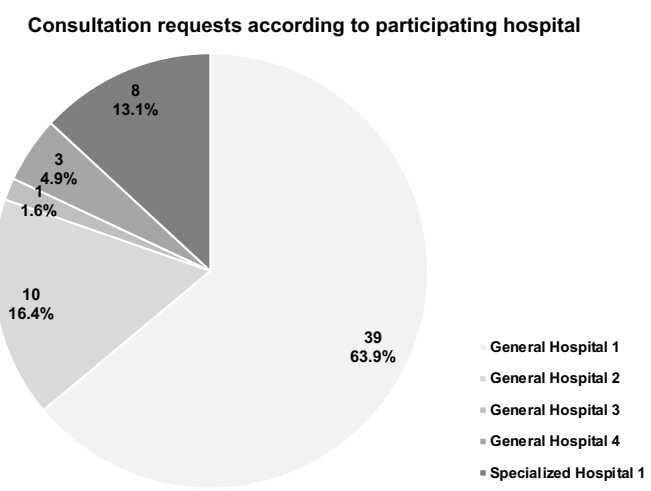

D

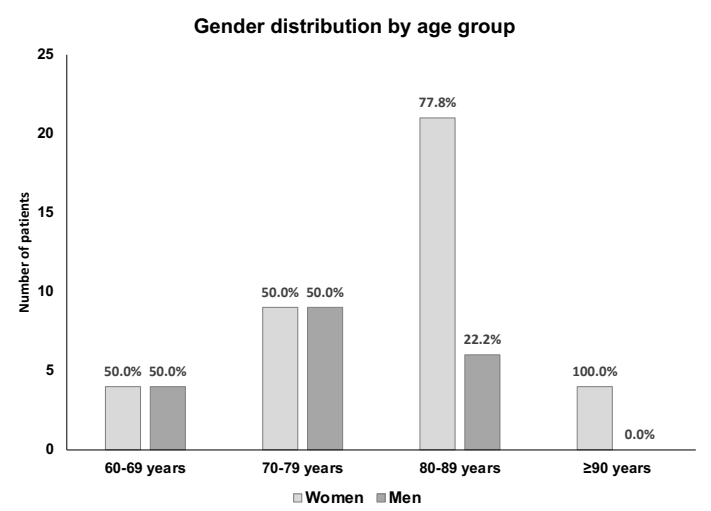


medRxiv preprint doi: https://doi.org/10.1101/2021.10.14.21264940; this version posted October 18, 2021. The copyright holder for this preprint (which was not certified by peer review) is the author/funder, who has granted medRxiv a license to display the preprint in It is made available under a CC-BY-NC-ND 4.0 International license.

Figure 2: Clinical history and indications for consultations. A: Reasons leading to initial admission of the patients. B: Symptoms reported by requesting institutions. C: Specific indications for consultation. Total numbers sum to $>100 \%$ as multiple items could be reported for one patient.

A

Reasons for initial admission

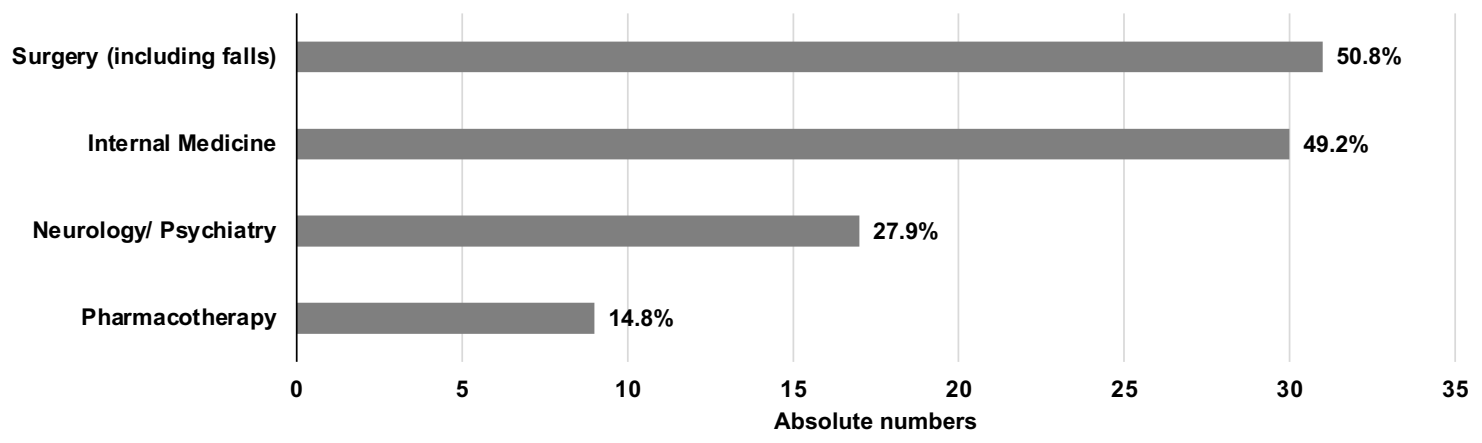

B

Symptoms reported by requesting institutions

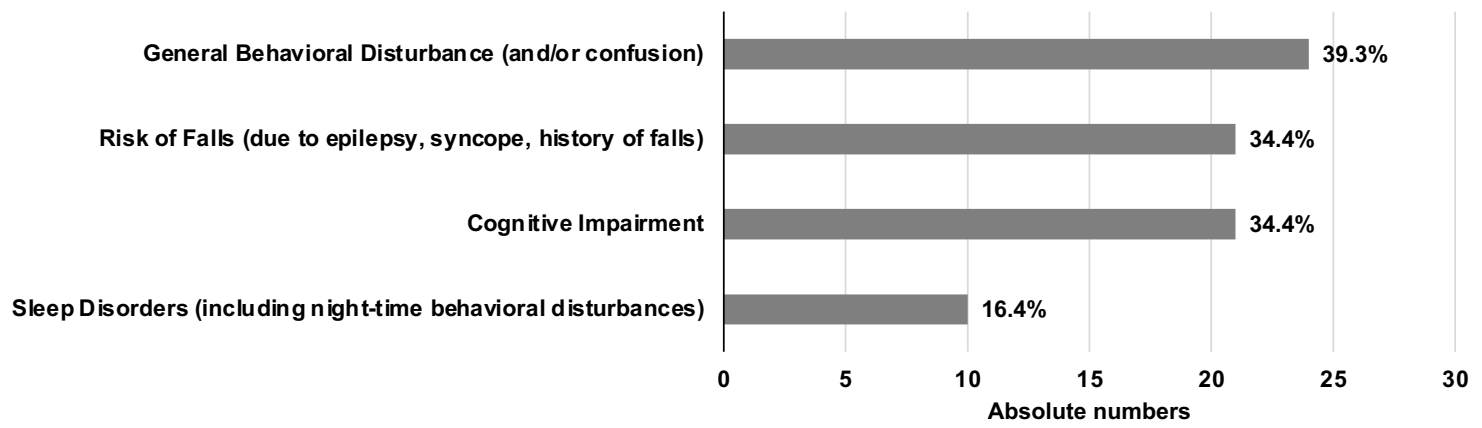

C

Indications for consultation

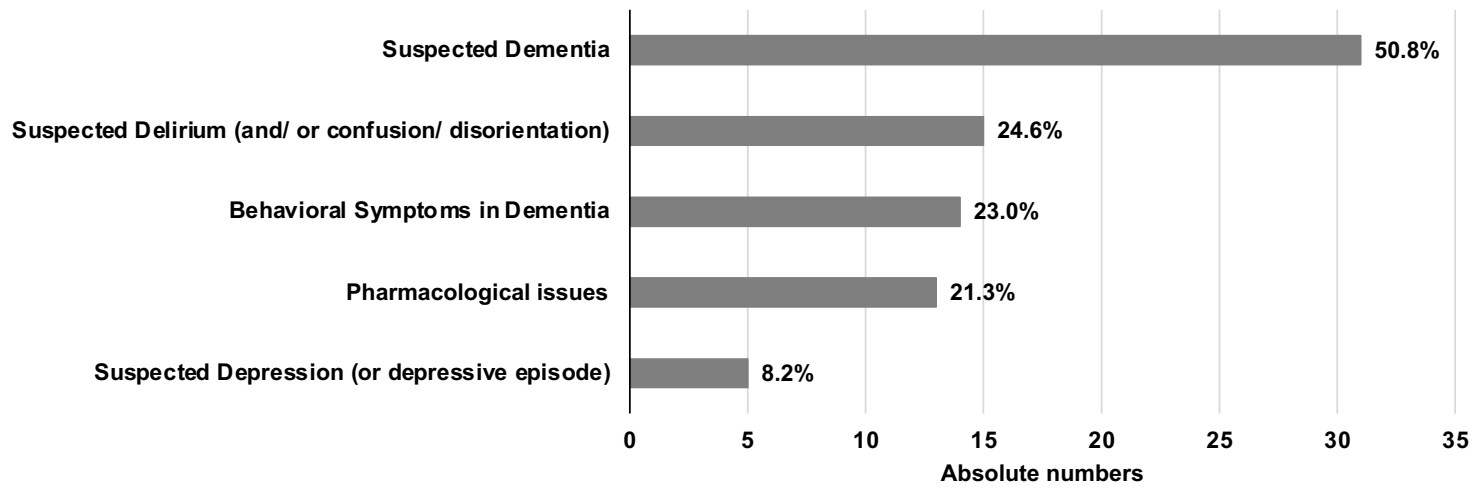


medRxiv preprint doi: https://doi.org/10.1101/2021.10.14.21264940; this version posted October 18, 2021. The copyright holder for this preprint (which was not certified by peer review) is the author/funder, who has granted medRxiv a license to display the preprint in It is made available under a CC-BY-NC-ND 4.0 International license.

Figure 3: Clinical history related to dementia and risk for delirium. A: Proportions of patients with recorded history of dementia (left) or cognitive deficits (right), respectively. B: Risk factors for developing delirium. Total numbers sum to $>100 \%$ as multiple items could be reported for one patient.

A

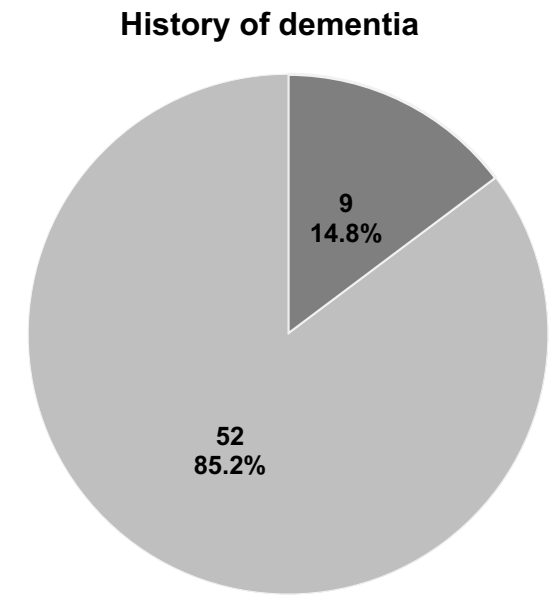

- Yes

$\square$ No or no information
Pre-existing cognitive deficits

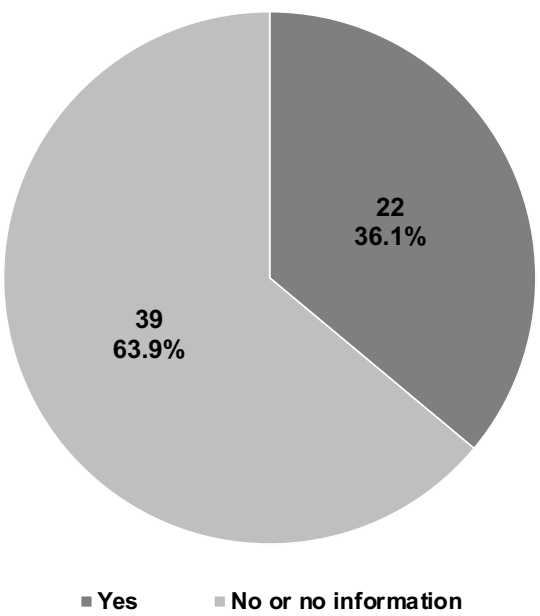

B

Risk factors for developing delirium

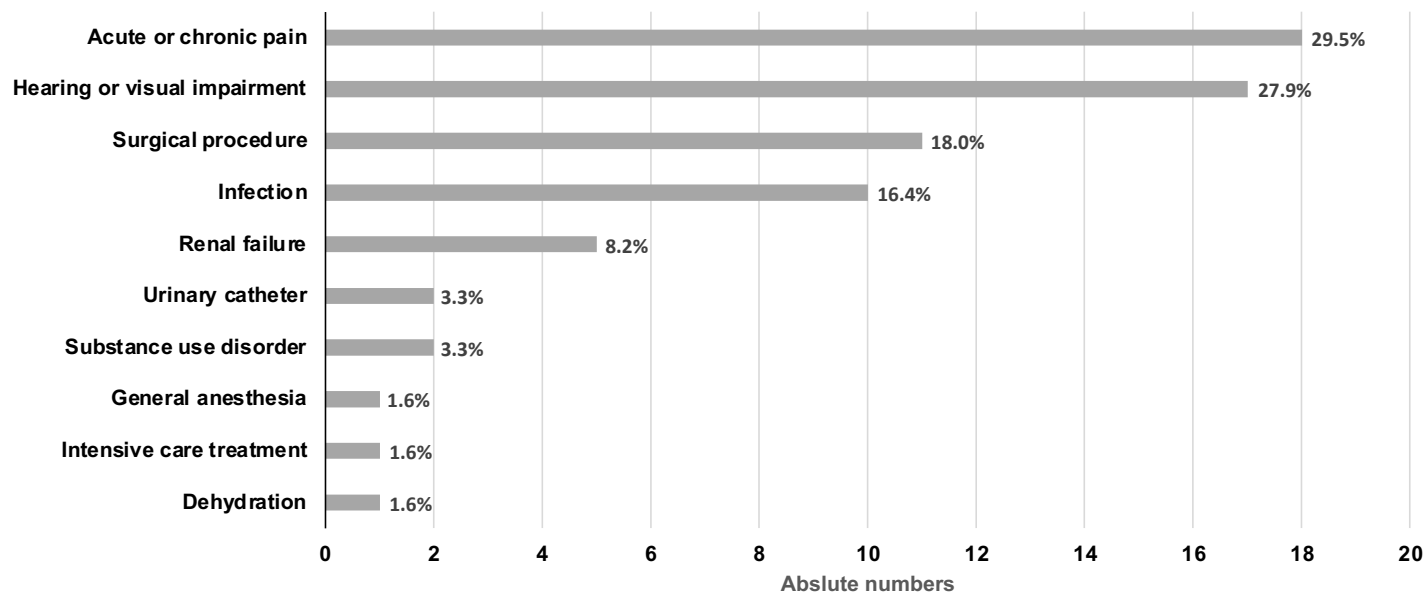


medRxiv preprint doi: https://doi.org/10.1101/2021.10.14.21264940; this version posted October 18, 2021. The copyright holder for this preprint (which was not certified by peer review) is the author/funder, who has granted medRxiv a license to display the preprint in It is made available under a CC-BY-NC-ND 4.0 International license.

Figure 4: Diagnostic assessment during consultations. A: Primary diagnoses noted by the consulting physicians. B: Proportions of dementia subtypes among patients diagnosed with any form of dementia. Medium grey denotes the (suspected) presence of Alzheimer's pathology. Hatch fill denotes (suspected) vascular pathology. C: MMSE scores among the patients investigated during consultations. D: Number of pharmacological agents taken by the patients.

A

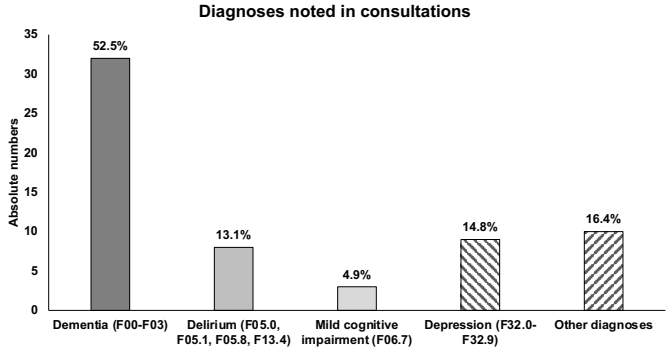

C

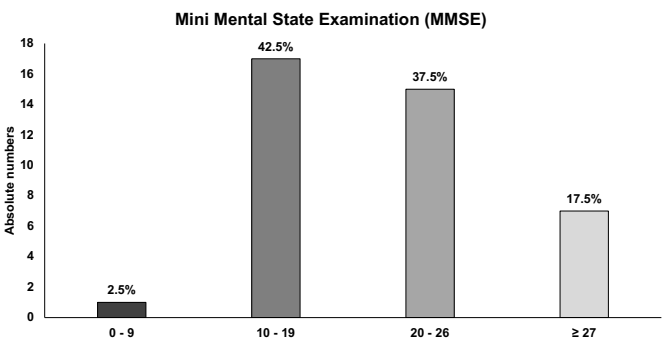

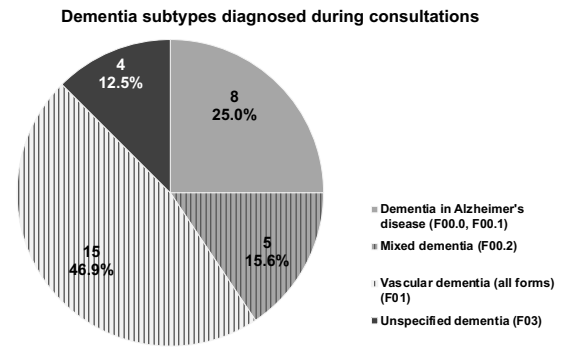

D

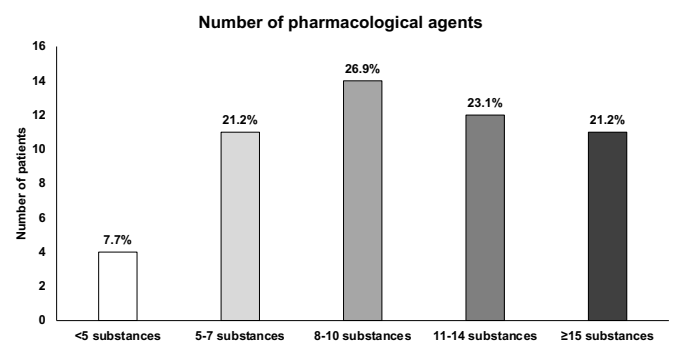


medRxiv preprint doi: https://doi.org/10.1101/2021.10.14.21264940; this version posted October 18, 2021. The copyright holder for this preprint (which was not certified by peer review) is the author/funder, who has granted medRxiv a license to display the preprint in It is made available under a CC-BY-NC-ND 4.0 International license.

Figure 5: Therapeutic recommendations. A: General recommendations. B: Pharmacological recommendations. Total numbers add to $>100 \%$ as multiple recommendations could be given for one patient.

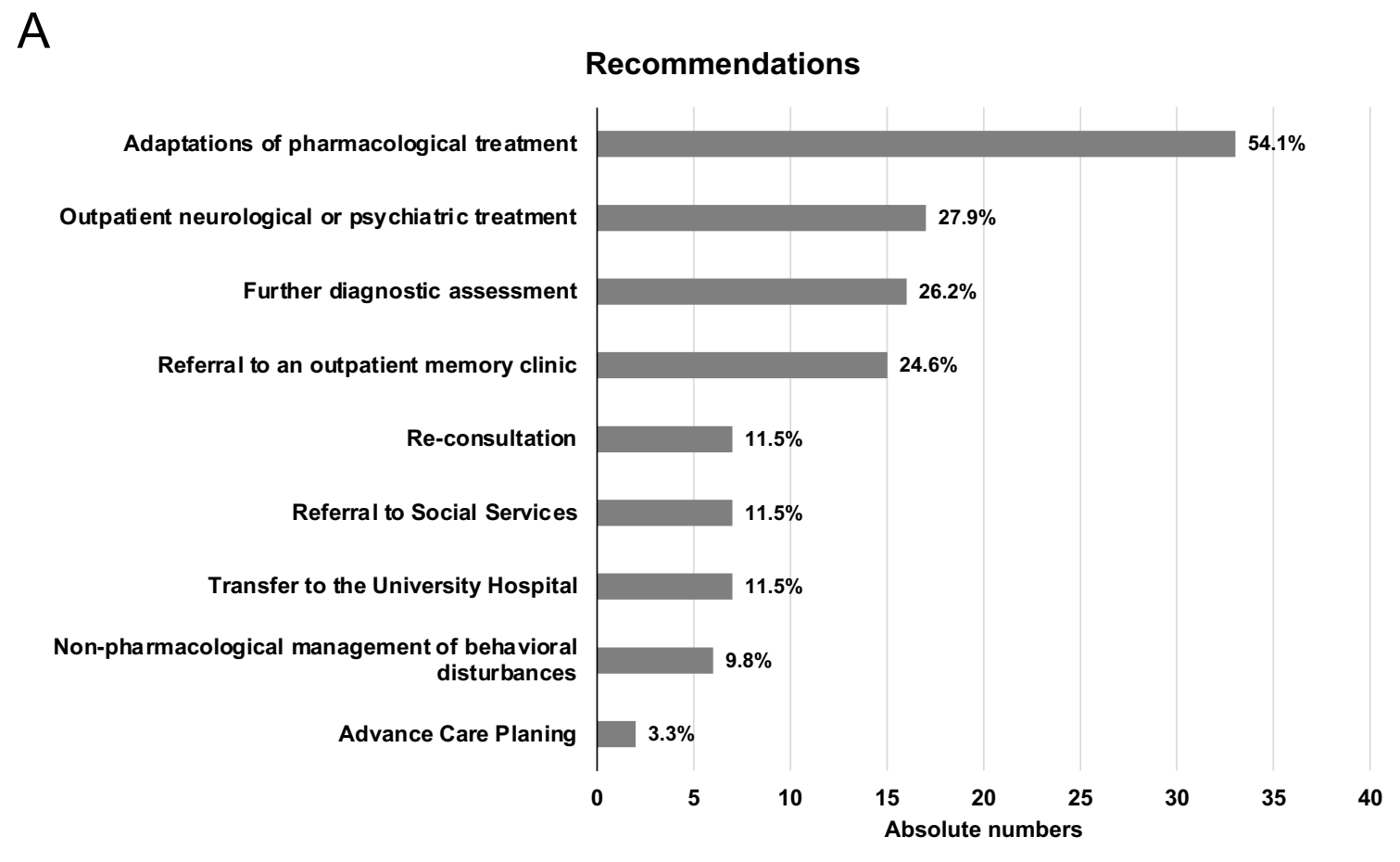

B

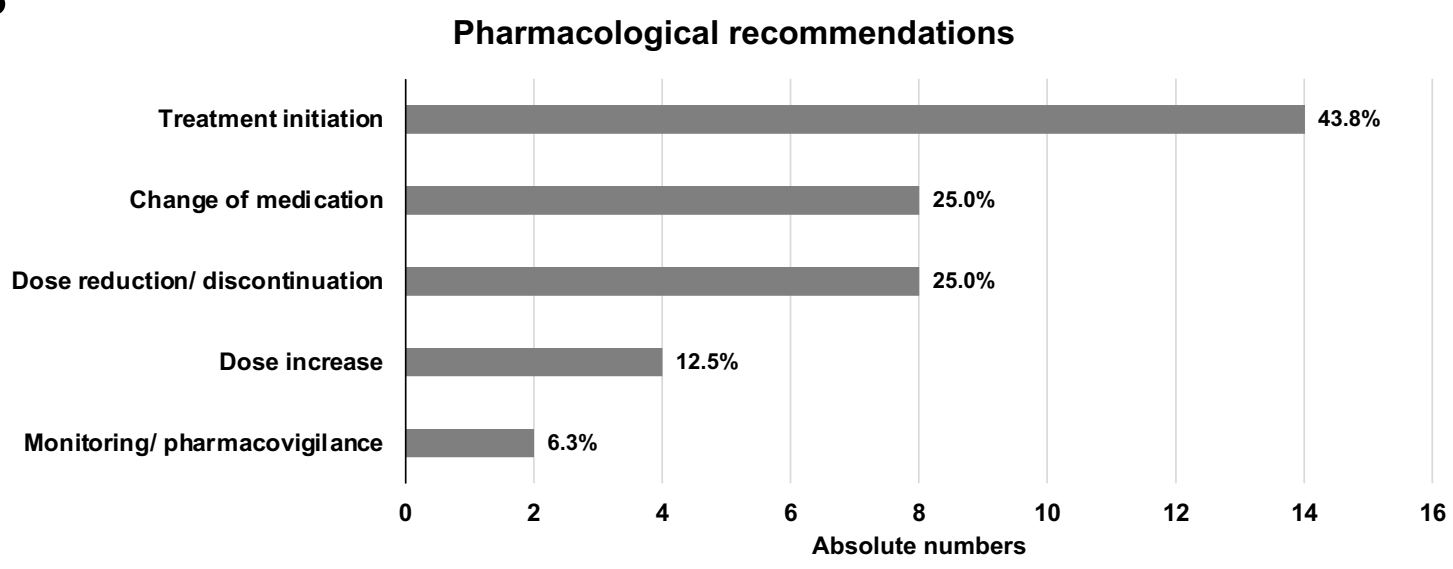

